\title{
PIPE EMPLACEMENT MODEL OF THE LOMONOSOV DIAMOND DEPOSIT, ARKHANGELSK REGION, NW RUSSIA
}

\author{
Ivan Mahotkin ${ }^{1}$, Jock Robey ${ }^{2}$, Stephan Kurszlaukis ${ }^{3}$, Eugeniy Valuev ${ }^{4}$, Nikolay Pylaev ${ }^{4}$ \\ ${ }^{1}$ De Beers, Russia; ${ }^{2}$ De Beers Geology Division, South Africa $;{ }^{3}$ De Beers GeoScience Centre, South Africa $;{ }^{4}$ Severalmaz, \\ Russia
}

\section{INTRODUCTION}

A drilling program carried out by De Beers and Severalmaz in 1998-2000 of the Lomonosov deposit gave the authors an opportunity to re-examine the geological models of the Arkhangelskaya as well as the Karpinskiy-1 and -2 pipes which had been previously described by Grib et al. (1987), Sablukov (1987) and Krotkov et al. (2001). With our new data, pipe emplacement models for the respective pipes are developed and presented. The authors used their terminology in a descriptive sense. Thus, terms like "diatreme" and "tuffisitic" are used in a purely morphological, descriptive and non-genetic sense.

\section{General Geology}

The Arkhangelskaya, Karpniskiy-1 and -2 pipes are located within 200-800 $\mathrm{m}$ of each other and form southern part of the Lomonosov diamond deposit.

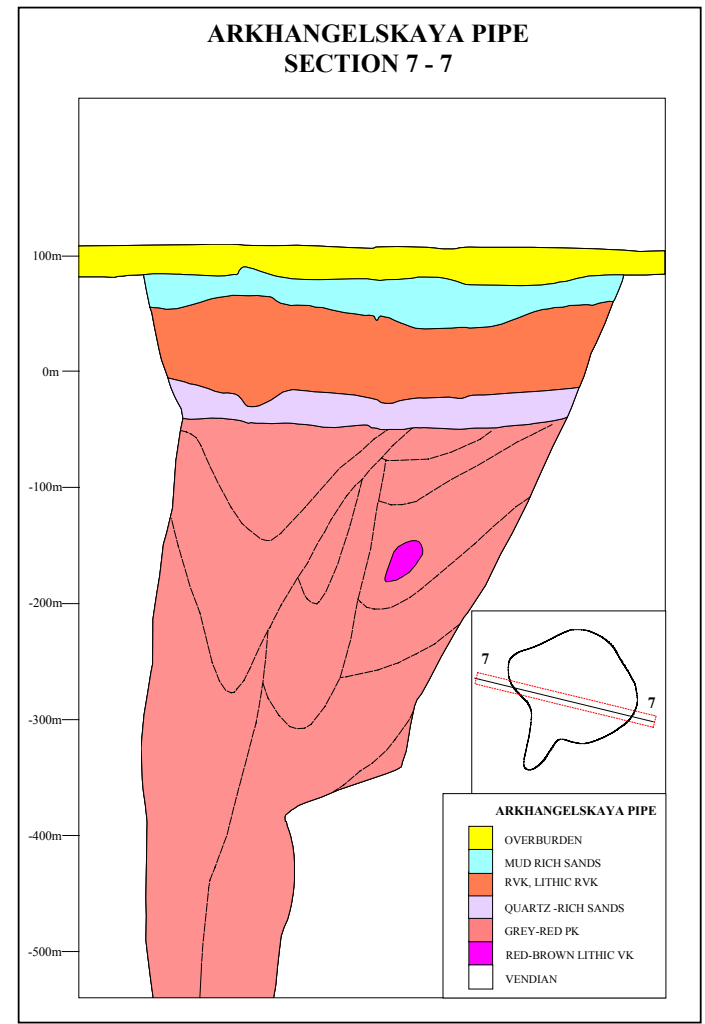

Figure 1: Arkhangelskaya pipe
A sub-meridian fracture zone controls the position of the pipes. The country rocks comprise clastic sediments of Vendian age (900 $\mathrm{m}$ in thickness) which overlying Archaean granite-gneisses and amphibolites. The Arkhangelskaya and Karpinskiy-1 pipes form single carrot-shaped diatremes (Figure 1 and 2), whereas the Karpinskiy-2 pipe comprises several carrot-like and bowl-shaped diatremes located along a sub-meridian fault (Figure 3). Multiple diatremes in Karpinskiy-2 suggests that the eruption centre migrated along a fault during pipe formation.

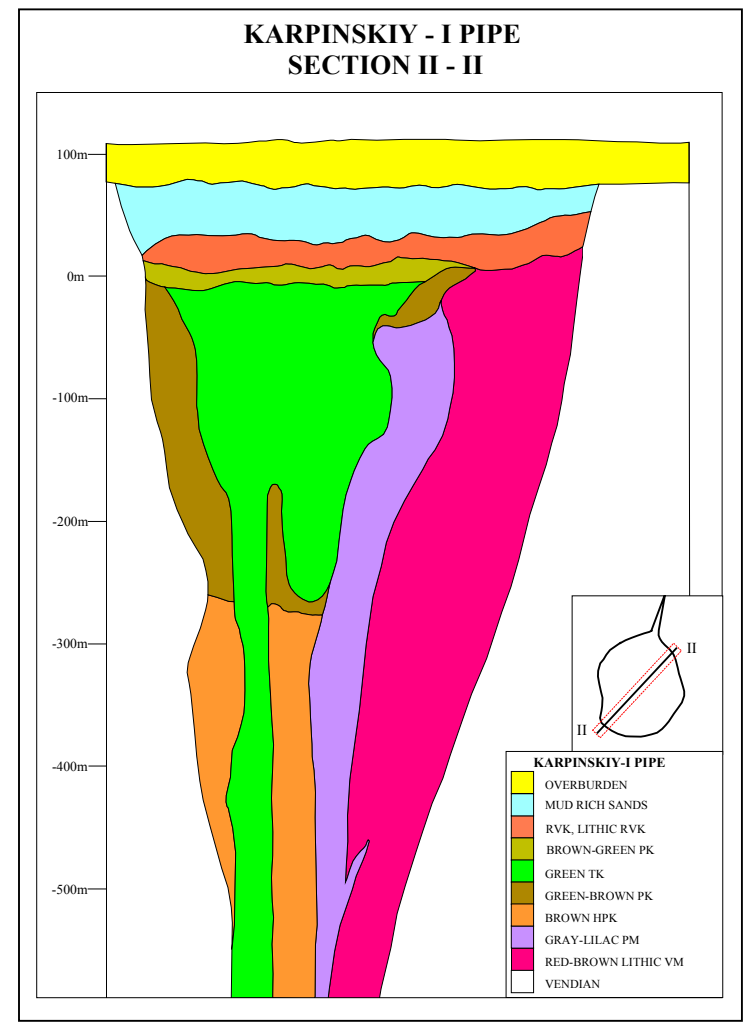

Figure 2: Karpinskiy-1 pipe

There are considerable differences in the internal structures of the pipes. Compositions of magmaclasts indicate that both the Arkhangelskaya and Karpinskiy-2 pipes were formed by kimberlite magma only. In contrast, the Karpinskiy-1 pipe was formed by two types of magma: poorly diamondiferous melnoites (or melilite-rich kimberlite) emplaced during the first stage 
and highly diamondiferous kimberlites during the second stage of formation.

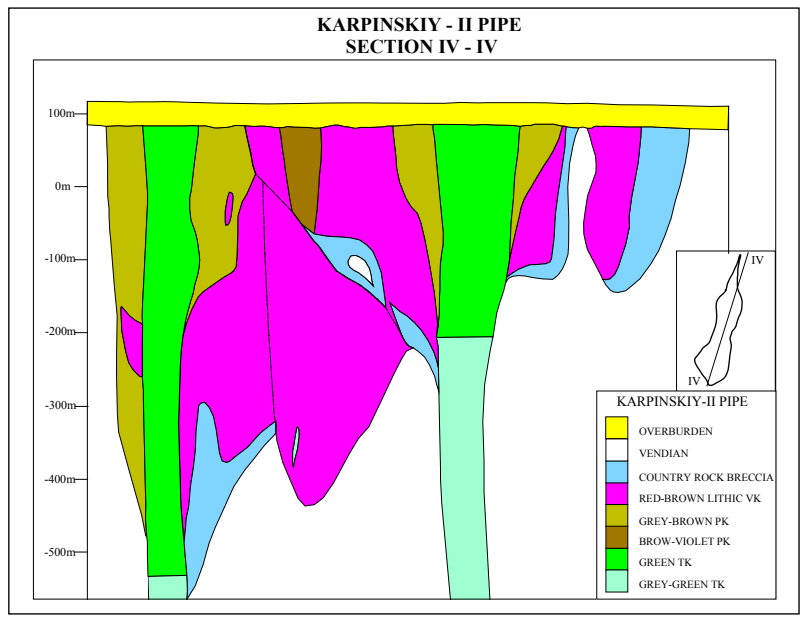

Figure 3: Karpinskiy-2 pipe

Emplacement age of the pipes has been estimated as Upper Devonian (370 Ma) by Sablukov (1987) and the pre-eruptive land surface is not preserved due to the Early Carboniferous erosion. At present the pipes are overlain by marine carbonaceous sandstones that are Middle Carboniferous (310 Ma). Erosion since the emplacement of the Arkhangelskaya pipe is assumed to be near $75 \mathrm{~m}$.

MAAR CRATER, SCORIA CONES AND ROCKS OF THE UPPER DIATREME

Horizontally bedded successions which occur throughout the upper diatremes of the Arkhangelskaya and Karpinskiy-1 pipes comprise red-brown lithic-rich and very lithic-rich clast-supported fragmental kimberlites and clastic sediments with a low abundance of volcanic material. Thicknesses of the successions vary from 120 to $160 \mathrm{~m}$. The successions were formed by erosion of the tephra rings that surrounded the craters, the pre-eruptive paleo-land surface and the maar crater walls. The level of the crater floors subsidised during compaction of the underlying diatreme-fill. The lithic-rich and very lithic-rich clastsupported fragmental kimberlites are interpreted as redeposited volcaniclastic kimberlites (RVK) and lithic RVK, respectively. The base of the epiclastic succession in the Arkhangelskaya pipe is defined by a $20 \mathrm{~m}$ thick layer of red quartz sands and glauconite sandstone blocks (Figure 1). They are interpreted as partially re-worked mass flows which originated from the crater walls of weakly consolidated Vendian quartz glauconite sandstones. The presence of the quartz-rich clastic sediments demonstrates that immediately following the close of primary volcanic activity the crater floor was situated below the pre-eruptive surface and that the crater was a wide maar.

The absence of quartz-rich clastic sediments at the base of the epiclastic succession in Karpinskiy-1 pipe, a gradual transition of the epiclastic sediments into the brown-green low-country rock xenoliths (CRX) pyroclastic kimberlites, as well as a slightly positive relief compared to the adjacent earlier formed lithic volcaniclastic melnoites suggests that the kimberlite volcano at the final stage of primary activity formed a scoria cone (Figure 2). The crater floor was above of the pre-eruptive land surface. Compaction of the diatreme infill resulted in formation post eruptive caldera. As subsidence within the pipe increased and the surrounding tephra ring was eroded, mud-rich volcaniclastic sands filled the upper part of the caldera depression.

The absence of epiclastic successions at shallow levels in the Karpinskiy-2 pipe indicates either that the pipe was formed earlier and epiclastic sediments were already eroded at the time of emplacement of Arkhangelskaya and Karpinskiy-1 pipes, or that there were no conditions for final intensive inter-crater subsidence of the underling diatreme rocks (Figure 3).

\section{DIATREME INFILLS}

The Arkhangelskaya diatreme is filled with clastsupported grey-red fragmental kimberlites. These rocks are interpreted as pyroclastic kimberlites (PK). The rhythmic interlaying of is well developed throughout the upper and middle diatreme (Figure 1). Thicknesses of the rock sequences vary within the pipe but generally increase from $20 \mathrm{~m}$ in shallow levels to $100 \mathrm{~m}$ in deeper levels of the diatreme. Almost throughout the diatreme, bedding of the sequences appears distorted and steep bedding angles prevail. This is likely the result of intensive local subsidence of tephra deposits towards the central portions of the pipe and repeated eruptions during the life span of the volcano. The red colour of the kimberlites prevails in the upper parts of each sequence and is caused by an increased abundance of close packed magmaclasts coated with a red oxidised film $(5-30 \mu \mathrm{m}$ in thickness). The beds do not show internal gradation but the proportion of matrix material increases towards the base of the sequences. We interpret the sequences as primary tephra fall deposits whose top layer was sufficiently hot enough after deposition to support oxidation of the magmaclasts that were in contact to the air. Thus the entire upper and middle diatreme comprise a series of several intersecting pyroclastic successions. Vesicles that occur 
in the inter-clast matrix and in the glassy magmaclasts at a depth of $-380 \mathrm{~m}$ below sea level (bsl) confirm the volcanic nature of the grey-red fragmental kimberlite. Down to $-670 \mathrm{~m}$ bsl the matrix magmaclasts (defined as $<0.5 \mathrm{~mm}$ in size) are very fine-grained, generally between $50-250 \mu \mathrm{m}$ in size and are spherical in shape. Rare, smaller magmaclasts of 5-15 $\mu \mathrm{m}$ size are shardlike and may represent interactive particles typically produced in thermohydraulic explosions (Büttner et al., 1999).

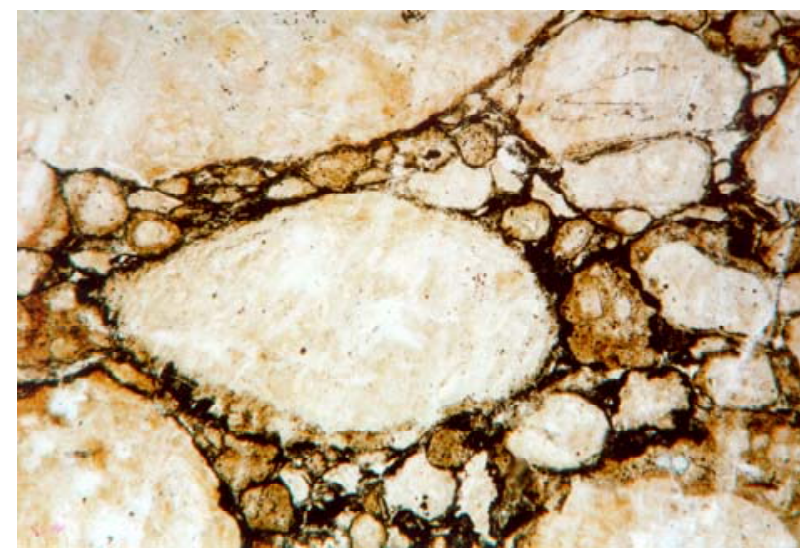

Figure 4: Green-brown pyroclastic kimberlite from Karpinskiy-1 (sample LD7/149, FOV- 3 mm)

In the Karpinskiy-1 pipe, structural and textural features of the matrix magmaclasts in the green-brown fragmental kimberlites of the second phase (Figure 4) and in the grey-lilac fragmental melnoites of the first phase are similar to those in the grey-red pyroclastic kimberlites of the Arkhangelskaya pipe. However the magmaclastes are more coarse-grained, ranging between 150-350 $\mu \mathrm{m}$. Similar ash grains are also present in the grey-brown and brown-violet fragmental kimberlites that comprise the upper and middle diatremes of the Karpinskiy-2 pipe, allowing their interpretation as pyroclastic rocks. Matrix clinopyroxenes occur only in grey-lilac pyroclastic melnoites in the Karpinskiy-1 pipe.

Brown fragmental kimberlites occur within a steep vertical column in the lower diatreme of the second phase of the Karpinsky-1 pipe below $-270 \mathrm{~m}$ bsl. These rocks are homogeneous and small-scale bedding is not apparent. The inter-clast matrix of those rocks consists of numerous phlogopite laths, interstitial serpentine, apatite prisms and hydrogarnet. At shallow levels the brown fragmental kimberlites contain some fragments of juvenile and slightly irregular-shaped pyroclasts (Figure 5). These rocks are interpreted as homogenised, highly metasomatic altered pyroclastic kimberlites (HPK). They probably represent the infill of the volcanic vent that originated from the root zone of the second phase of the Karpinsky-1 pipe.

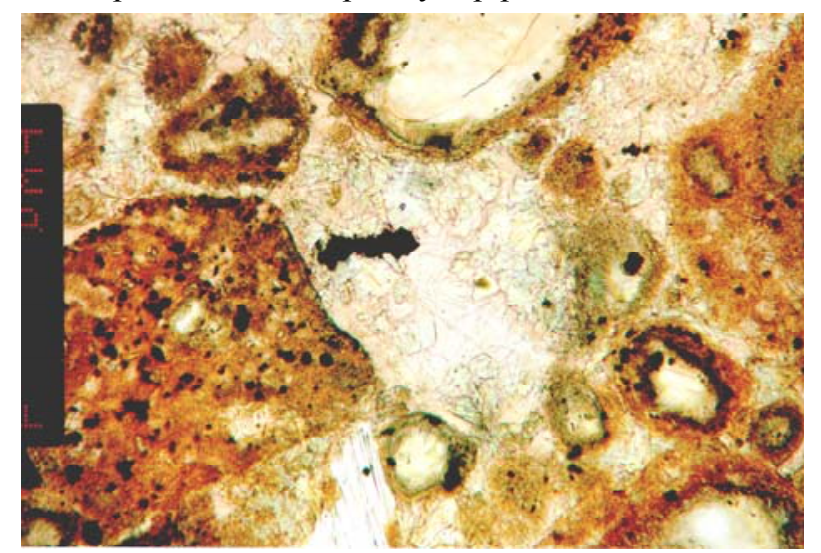

Figure 5: Brown fragmental kimberlite from Karpinskiy-1 pipe The slightly irregular-shaped magmaclasts partially rimmed by an opaque ferrous film suggest oxidation at the contact to air. A pyroclastic nature of this rock is suggested. (Sample LD7/400, FOV- 3 mm).

Green fragmental kimberlites, which are similar to typical tuffisitic kimberlite breccias of the diatreme facies (Clement and Skinner, 1985), form a large central body that widens in the upper diatreme of the second phase of Karpinskiy-1 and also two narrow columns in Karpinskiy-2 (Figure 2 and 3). The matrix magmaclasts in the green fragmental kimberlites are generally $150-350 \mu \mathrm{m}$ in size, that is similar to the adjacent green-brown and grey-brown pyroclastic kimberlite. The main features of the green fragmental kimberlite include a predominately matrix-supported texture, a relatively homogeneous structure, a high degree of alteration of matrix magmaclasts as a result of hydrothermal re-crystallisation, and an abundance of large, spherical magmaclasts with multiple magmatic rims. The latter concreted around large olivine macrocrysts or angular cores of uniform and segregationary textured kimberlite fragments. The green fragmental kimberlites are classified as tuffisitic kimberlite (TK). The green TK could be interpreted either as rocks formed during fluidisation of the brown HPK and further injection of highly homogeneous material into the upper levels of the diatreme or as infilling of the volcanic feeder vents. After a thermohydraulic explosion, infilling material transported from the root zone to the surface. TK and PK are considered as one rock type, "autolithic breccia", in Russian terminology (Grib et al. 1987, Krotkov et al., 2001).

The red-brown lithic-rich fragmental kimberlites or lithic-rich fragmental melnoites ("xenotuff breccia" in 
Russian terminology) comprise large bodies adjacent to country rocks in Karpinskiy- 1 and -2 pipes and also occur as large accidental blocks inside the grey-red pyroclastic kimberlite of the Arkhangelskaya pipe. They are classified as lithic volcaniclastic kimberlite (VK) and lithic volcaniclastic melnoites (VM) that are characterised by a pronounced mixture of country rock xenoliths (Vendian sediments) and juvenile volcanic material, a crude layering ( $\sim 15-30 \mathrm{~m}$ thickness, especially in the upper part of the succession), accretionary lapilli, slightly in-coaled Upper Devonian wood remnants (down to $-500 \mathrm{~m}$ bsl) and blocks derived from country rock landslides. The fine-grained volcanic material has been completely altered to saponite. The predominance of saponite is probably as a result of the extremely fine grain size $(2-7 \mu \mathrm{m})$ of the ash particles which are extremely sensitive to alteration in the presence of water. The lithic VM or VK contain an abundance of liberated xenogenous quartz grains, usually 2-4 times larger than the size of the quartz grains in the Vendian county rock xenoliths. The coarse quartz grains occur throughout the whole lithic VM and VK succession and probably originate from the unconsolidated quartz-rich sands that are present only in the upper levels of the Vendian cover. The large (up to $15 \mathrm{~m}$ ) blocks of Vendian country rocks in the lithic VM or VK are likely landslide structures dipping towards two vertical columns of green tuffisitic kimberlite (Figure 3). VM and VK are interpreted as primary pyroclastic and re-sedimented rocks originally deposited on the maar crater floor and further transformed into deeper levels of the diatremes by intracrater subsidence.

The contact between the lithic VM or VK bodies and the country rock is usually defined by zones of intensively brecciated country rock. The latter are well preserved in the northern keel-like part of Karpinskiy-2 (Figure 6). Here, the narrow vein-like occurrence of VK is surrounded by a wide zone of kimberlite-free country rock breccias that could represent contact breccias (Clement,1982). Metasomatic enrichment in Re, Mo, $\mathrm{Rh}$ in this zone at depths of $-300 \mathrm{~m}$ bsl in the Arkhangelskaya pipe may reflect a high-temperature fluid halo of the lower diatreme.

\section{CONCLUSION}

At Karpinsky-2 many structural features of the lithic VM and lithic VK can be explained by high energy phreatomagmatic eruptions. During the entire period of lithic VM and lithic VK formation, the crater was maartype with country rocks that were exposed in the crater wall contributing coarse-grained quartz to the crater floor. The formation of lithic volcaniclastic rocks was accompanied by intra-crater subsidence of the underlying volcaniclastic succession. Initial explosions were close to the land surface and further growth of the diatreme towards depth was accompanied by the remobilisation of material from the country rock breccia zone (Figure 7).

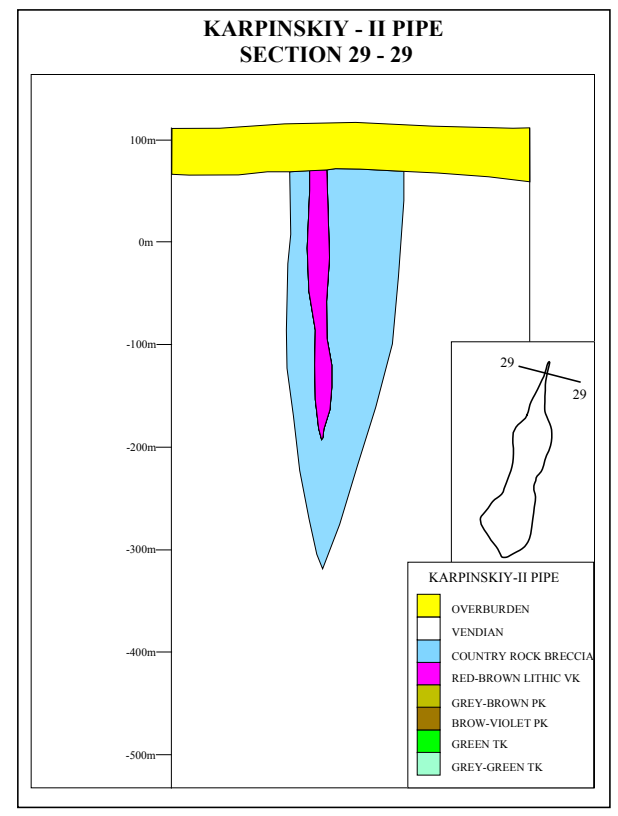

Figure 6: Karpinskiy-2 pipe

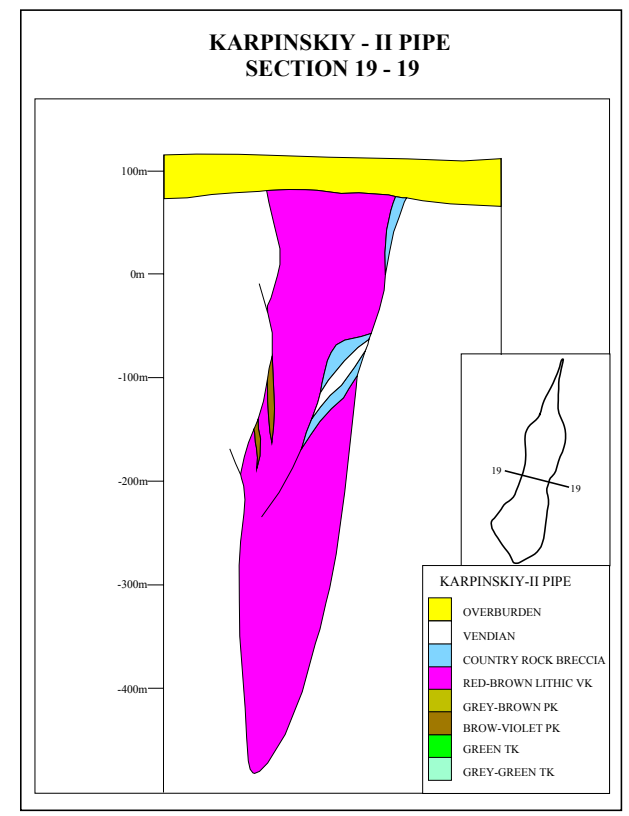

Figure 7: Karpinskiy-2 pipe

The origin of grey-red and green-brown pyroclastic kimberlites in the Arkhangelskaya and Karpinskiy-1 
pipes is related to less powerful thermohydraulic explosions. The volcano during this phase was likely a scoria cone where the crater floor was above the level of the pre-eruptive land surface. This limited the input of xenogenous quartz grains from the upper levels of the Vendian country rocks into the grey-red and greenbrown kimberlite tephra.

The waning stage of volcanic activity in the Arkhangelskaya pipe was accompanied by a strong high-energy explosion that resulted in the formation of the final maar crater. Another style of waning volcanic activity can be observed in the Karpinskiy-1 pipe where explosives gradationally seized and were accompanied by emplacement of the green TK (Figure 2).

Although the Lomonosov pipes were formed contemporaneously in the same geological environment and are located close to each other, they differ considerably in their internal structure and in the textural appearance of their kimberlite types. These differences and many other features of the pipes can not be adequately explained by the fluidisation emplacement model as proposed by Clement and Skinner (1985) and Field and Scott-Smith (1999). The fluidisation model is also not applicable due to the absence of hard cap rocks in the Vendian cover that would be necessary for creating fluid overpressures and fluidisation the kimberlitic melt. However, six extensive aquifers in the Vendian sediments and presence of the fracture zone created favourable conditions for phreatomagmatic explosions. It is believed that the Lomonosov pipes formed due to the interaction of numerous injections of kimberlite magma into water saturated, poorly consolidated clastic country rocks of Vendian age. The proposed pipe emplacement model of the Lomonosov kimberlites is compatible with the phreatomagmatic models of Lorenz (1985). Differences between the Lomonosov pipe structures resulted from variable phreatomagmatic explosions whose intensity depended on the mixing ratio of water reacting with kimberlite magma (Wohletz, 1983). A change in this ratio can be caused by inhomogeneities within the aquifers or interaction of several closelyspaced groundwater table depressions ("funnels") developing during contemporaneous volcanic activity within the pipe cluster.

\section{REFERENCE}

Büttner, R., Dellino, P. Zimanowski, B. 1999. Identifying magma-water interaction from the surface textures of ash particles. Nature, 401, 688-690.

Clement, C.R. 1982. A comparative study of some major kimberlite pipes in the Northern Cape and Orange Free State. Ph.D. Thesis, Univ. Cape, South Africa.

Clement, C.R, Skinner, E.W. 1985. A textural-genetic classification of kimberlites. Trans. Geol. Soc. S. Afr. 88, 403-409.

Grib, V.P, Scripnichenko, V.A, Shchukin, V.S. 1987. Alkaline-ultramafic magmatism of the northern margin of the Russian platform. In: Geology and Ore deposits in the Northern Russian platform. Moscow: Geolfond proceedings, pp. 66-74 (in Russian).

Field, M, Scott Smith, B.H. 1999. Contrasting geology and Near-Surface Emplacement of kimberlite pipes in the Southern Africa and Canada; Proceedings of the Seventh Int. Kimberlite Conf. Cape Town, pp. 214-237.

Krotkov, V.V. et al. 2001. New technologies of diamond deposits exploration. GEOS, Moscow, (in Russian).

Lorenz, V 1985. Maars and diatremes of phreatomagmatic origin: a review. Trans. Geol. Soc. S. Afr. 88, 459-470.

Sablukov, S.M. 1987. Some peculiarities of the internal structure of kimberlitic pipes. Moscow: TsNIGRI proceedings, 218, pp. 37-41 (in Russian).

Wohletz, K.H. 1983. Mechanisms of hydrovolcanic pyroclast formation: Grain size, scanning electron microscopy, and experimental results. J. Volcanol. Geotherm Res., 17, 31-63.

Contact: IL Mahotkin, Chayanova Street 7, Moscow,125047, Russia, E-mail: imahotkin@debeers.ru 